\title{
PEMBERDAYAAN PEREMPUAN MELALUI GERAKAN LITERASI DI ERA DIGITAL
}

\author{
Syahdara Anisa Makruf ${ }^{1}$, Fuad Hasyim ${ }^{2}$ \\ ${ }^{1}$ Universitas Islam Indonesia, Yogyakarta, Indonesia \\ 2, Universitas Islam Indonesia, Yogyakarta, Indonesia \\ email(133100508@uii.ac.id, fuad.hasyim@uii.ac.id)
}

\begin{abstract}
ABSTRAK
Kekerasan perempuan di era digital saat ini menjadi perhatian bersama, salah satunya adalah adanya kesenjangan akses dan literasi digital. Metode pengabdian ini dilakukan dengan cara membentuk komunitas perempuan yang tertarik dengan isu pemberdayaan perempuan. Pendekatan pengabdian menggunakan pendekatan andragogi. Kasus yang diangkat adalah masih banyaknya kekerasan perempuan di era digital yang menyebabkan ketidakberdayaan bagi perempuan. Teknis pengabdian dilaksanakan dengan beberapa tahapan, yakni tahapan kualifikasi peserta, tahapan pelaksanaan workshop kepenulisan dan tahapan rencana tindak lanjut. Hasil pengabdian yakni peserta mengalami perubahan tingkat pemahaman yakni sebesar $45 \%$ tentang strategi dan metode menulis di media massa. $37 \%$ pemahaman peserta meningkat tentang isu kekerasan perempuan di media massa. $30 \%$ peserta termotivasi untuk berdakwah dengan menulis isu perempuan melalui media massa. Pemberdayaan perempuan penting dilakukan sebagai upaya untuk memaksimalkan potensinya. Setiap perempuan memiliki kesempatan untuk mengatualisasikan dirinya dengan melibatkan diri untuk berdakwah di masyarakat. Di era digital saat ini, perempuan harus adaptif dengan perkembangan Ilmu Pengetahuan dan Teknologi (IPTEK) untuk melakukan perubahan kondisi sosial masyarakat.
\end{abstract}

Kata Kunci: Pemberdayaan Perempuan, Dakwah, Literasi Digital

\section{PENDAHULUAN}

Pemberdayaan perempuan merupakan salah satu sasaran utama rencana pembangunan yang tertuang dalam RPJM 2005-2025. Pencantuman ini bertolak dari tingkat partisipasi perempuan dalam pembangunan yang dianggap masih belum ideal. Selain itu, kondisi perempuan Indonesia juga masih tergolong sebagai kelompok masyarakat rentan dalam bidang sosial maupun ekonomi. Data BPS (Badan Pusat Statistik, 2019) menunjukkan bahwa 7,47\% perempuan berusia 5 tahun ke atas tidak bersekolah. Sementara, 3 dari 10 perempuan berusia 16-18 telah mengalami putus sekolah. Dengan kondisi pandemi yang masih luas, para perempuan bahkan menghadapi tantangan semakin berat, khususnya para perempuan kepala rumah tangga dan prasejahtera. Data Kementerian Pemberdayaan Perempuan dan Perlindungan Anak Indonesia menunjukkan dari sekitar 2385 pekerja yang mengalami PHK akibat pandemi, 31\% adalah perempuan (KPPPAI, 2020). Di samping itu, tanggung jawab mendampingi anak- anak dalam belajar secara daring menjadi beban ganda bagi mereka, khususnya para perempuan pekerja.

Pemberdayaan perempuan adalah upaya mendorong perempuan agar mampu mendapatkan akses terhadap sumber daya, ekonomi, politik, sosial, dan budaya. Dengan akses 
tersebut, mereka akan berdaulat dan memiliki kepercayaan diri untuk berperan aktif dalam mencari solusi atas problem masyarakat. Dalam konteks tersebut, pemberdayaan perempuan adalah proses sekaligus tujuan (Bappeda DIY, 2017). Pemberdayaan perempuan dapat dipandang sebagai strategi untuk mengembangkan potensi dan peran perempuan, baik di ranah publik maupun domestik. Dengan mempertimbangkan kompleksitasnya, maka pemberdayaan tersebut harus dilakukan oleh berbagai lapisan masyarakat termasuk organisasi perempuan Islam, karena lembaga tersebut dapat berkontribusi terhadap penguatan dan peningkatan kualitas hidup perempuan di bidang ekonomi, sosial, kesehatan, kesejahteraan dan pendidikan (Zakiyah, 2010). Pemberdayaan perempuan juga merupakan usaha untuk menciptakan kesetaraan dalam peran, akses, maupun kontrol antara perempuan dan laki- laki di segala bidang pembangunan masyarakat. Hal ini karena tujuan program pemerintah dan organisasi kemasyarakatan adalah terdistribusinya manfaat pembangunan, baik bagi laki- laki maupun perempuan (Puspita, 2016).

Pada era kontemporer saat ini, pemberdayaan perempuan menjadi sangat penting dan mendesak, karena pemberdayaan perempuan dapat berperan sebagai langkah penting untuk meningkatkan kapasitas perempuan agar dapat berkarya, mandiri, dan memiliki posisi tawar dalam persaingan global. Oleh karena itu, partisipasi perempuan dalam berbagai bidang pembangunan berfungsi sebagai media untuk mencapai kesetaraan akses di berbagai bidang. Bahkan, partisipasi perempuan dalam pembangunan telah menjadi parameter bagi negara dengan kategori maju (Suharli, 2021). Maka dari itu dapat dimaklumi jika pemberdayaan perempuan menjadi komitmen pemerintah, dalam hal ini Kementerian Pemberdayaan Perempuan dan Anak (KPPPA), untuk meningkatkan kesetaraan gender dalam berbagai bidang, ilmu pengetahuan, teknologi, teknik dan matematika (STEM), partisipasi kerja, dan memperkuat literasi keuangan dan digital (Purnamasari, 2021).

Memasuki era teknologi informasi dan digital, maka kapasitas yang harus dikembangkan dalam program pemberdayaan perempuan adalah literasi digital. Secara sederhana, literasi berarti kemampuan membaca, menulis, dan berhubungan dengan informasi. Kemampuan tersebut sangat menentukan bagaimana individu atau organisasi berkembang. Termasuk bagi mereka para perempuan, karena kemampuan mereka mengakses informasi secara efektif akan mereduksi keterbatasan mereka dalam menggunakan media digital (Widyastuti et al., 2016). Selanjutnya, dengan kemampuan tersebut, mereka dapat mengekspresikan gagasan dan pemikiran dengan berdampak yang luas.

Perkembangan media digital berbasis internet, pola interaksi dan komunikasi masyarakat pun mengalami perubahan secara cepat. Dengan demikian, individu yang memiliki literasi yang rendah akan mengalami kesulitan untuk mengekspresikan gagasan dan pemikiran secara efektif dan luas. Dalam konteks ini, gerakan literasi merupakan gerakan baru yang sangat dibutuhkan oleh perempuan, terutama bagi mereka para perempuan muda atau remaja yang sangat rentan terhadap arus informasi digital di media sosial (Mulyasih, 2017). Dengan demikian dibutuhkan literasi dalam bentuk kemampuan membaca atau menulis terlebih dengan memanfaatkan platform digital, seperti media massa, laman situs dan media sosial. 
Pemberdayaan perempuan melalui gerakan literasi diharapkan memiliki pengetahuan dan keterampilan mengenai kebutuhan, kemampuan mengidentifikasi, menemukan sumber, mengevaluasi, mengorganisir informasi, serta menciptakan, memanfaatkan dan mengkomunikasikan informasi secara efektif untuk mengatasi masalah yang dihadapi. Hal ini merupakan prasyarat untuk berpartisipasi dalam menciptakan kemajuan masyarakat dan bagian dari hak asasi manusia dalam hal belajar sepanjang hayat (Komariah, N, Prijana, dan Winoto, 2018).

Artikel ini akan menjabarkan program pengabdian masyarakat dengan tema pemberdayaan perempuan melalui gerakan literasi yang telah dilaksanakan oleh tim pengabdian bekerja sama dengan mitra pengabdian yakni Pimpinan Wilayah Nasyiatul Aisyiah di Daerah Istimewa Yogyakarta. Nasyiatul 'Aisyiyah (NA) merupakan organisasi khusus putri Islam yang kehadirannya memberikan dakwah secara inovatif kepada masyarakat. Melalui gerakan literasi, NA berupaya untuk melakukan emansipasi terhadap perempuan.

\section{Metode}

Pengabdian masyarakat ini bermitra dengan Pimpinan Wilayah Nasyiatul Aisyiyah Daerah Istimewa Yogyakarta. Pendekatan pengabdian menggunakan pendekatan andragogi yakni proses pembelajaran bagi oramg dewasa serta dalam menyelesaikan permasalahan menggunakan pendekatan studi kasus. Kasus yang diangkat adalah masih banyaknya kekerasan perempuan di era digital yang menyebabkan ketidakberdayaan bagi perempuan itu sendiri. Kualifikasi peserta adalah para aktivis perempuan yang paham bagaimana pandangan Islam terhadap perempuan dan peserta mampu melakukan gerakan literasi yang bertujuan untuk mengurangi adanya kekerasan terhadap perempuan di media massa. Teknis pengabdian dilaksanakan dengan beberapa tahapan, yakni tahapan kualifikasi peserta, tahapan pelaksanaan workshop kepenulisan dan tahapan rencana tindak lanjut.

Tahapan kualifikasi peserta, tim pengabdi berkoordinasi dengan mitra dan melakukan proses perekrutan kesertaan. Target peserta workshop berjumlah 30 orang yang memiliki latar belakang aktivis organisasi Islam yang tertarik pada isu keperempuanan baik di kalangan pelajar, mahasiswa dan para ibu muda dengan rentang usia 17 sampai 40 tahun. Peserta yang terpilih menjadi peserta workshop kepenulisan yang dilaksanakan aula pertemuan Jalan Kusumanegara Kota Yogyakarta Daerah Istimewa Yogyakarta. Workshop kepenulisan dilaksanakan secara luring dengan tetap menerapkan protokol kesehatan. Kegiatan workshop ini terdapat dua bagian materi pokok yakni materi tentang urgensi pemberdayaan perempuan, pentingnya dakwah perempuan kekinian khususnya di era digital dan strategi agar tulisan menembus media massa. Terakhir tahapan rencana tindak lanjut yakni setiap peserta mampu menghasilkan karya tulisan dalam rangka melakukan perubahan kondisi sosial 
kemasyarakatan melalui media massa, media sosial ataupun tulisan dalam bentuk jurnal ilmiah.

\section{Hasil dan Pembahasan}

Islam merupakan agama yang rahmatan lilálmin. Islam hadir untuk memuliakan perempuan. Laki-laki dan perempuan itu setara di hadapan Allah SWT. Maka, sudah menjadi kesadaran bersama untuk bisa memberikan kesempatan kepada perempuan untuk belajar maupun bekerja. Perempuan tidak memiliki halangan untuk bisa mengaktualisasikan dirinya untuk turut serta memberikan kemaslahatan kepada umat (Hanapi, 2015).

Setiap manusia memiliki potensi, begitu juga dengan perempuan. Perempuan merupakan makhluk Allah yang setara derajatnya dengan laki-laki. Perempuan patut mendapatkan dukungan untuk melejitkan potensinya. Lebih jauh, kebijakan publik pun harus ramah terhadap perempuan. Dalam hal ini bisa menjadikan perempuan untuk bisa mengaktualisasikan dirinya dengan memberikan kesempatan untuk berkiprah di segala bidang yang dikuasainya (Muhammad, 2014).

Hasil pengabdian yakni peserta mengalami perubahan tingkat pemahaman yakni sebesar $45 \%$ tentang strategi dan metode menulis di media massa. $37 \%$ pemahaman peserta meningkat tentang isu isu kekerasan perempuan di media massa. $30 \%$ peserta termotivasi untuk menulis isu perempuan melalui media massa. Peserta berjenis kelamin perempuan dan merupakan aktivis organisasi Islam di kalangan pelajar, mahasiswa dan ibu muda dengan rentang usia 17 sampai 40 tahun yang tertarik pada isu-isu keperempuanan. Isu-isu keperempuanan di era disrupsi terlebih kondisi pandemi menjadi menarik untuk diperbincangkan.

Isu kekerasan perempuan pun menjadi perhatian semua kalangan. Beban ganda bagi perempuan di masa pandemi ini menjadi pemikiran bersama. Hal inilah yang memberikan kesadaran kepada para aktivis perempuan untuk berjuang memberikan perlindungan dengan cara mengamankan hak-hak perempuan. Lebih jauh menyadarkan kepada masyarakat untuk memanusiakan perempuan dengan melakukan misi humanis. Kekerasan perempuan bisa dikurangi dengan pendekatan yang terintegrasi (Sasi, 2010).

Di era disrupsi saat ini, media massa mampu memainkan perannya dalam memberikan informasi tentang isu-isu krusial yang berkaitan dengan perempuan. Berbagai macam wacana perempuan yang disajikan di media massa telah memberikan pengaruh terhadap pemikiran para aktivis untuk bergerak mengampanyekan perlindungan terhadap hak-hak perempuan. Misi utama para aktivis perempuan adalah dalam rangka untuk memberdayakan perempuan agar mampu mencapai kesetaraan gender. Mereka memberikan kesadaran kepada masyarakat 
tentang pentingnya memberikan kesempatan yang sama bagi perempuan hadir sebagai subyek perubahan.

Subyek perubahan bagi perempuan modalnya ialah terletak pada kebaikan pekertinya, kecerdasan pemikirannya dan manfaat untuk keluarga dan masyarakat. Namun, permasalahannya adalah jika kita mencermati lebih jauh kecantikan perempuan yang menjadi bintang iklan di TV, masyarakat masih menganggap bahwa kecantikan perempuan adalah yang secara fisik dibuktikan dengan badan yang langsing, rambut panjang dan berkulit putih. Hal ini tentu akan menimbulkan kesalahan persepsi, kemunduran bagi perempuan itu sendiri bahkan ketimpangan sosial (Winarni Wahyu, 2010). Kesalahan persepsi bagi masyarakat dalam memberikan penilaian perempuan bisa diminimalisasi dengan hadirnya pendakwah di media massa.

Kehadiran para pendakwah di media massa menjadi sebuah gerakan pencerah yakni memberikan pengetahuan dalam rangka untuk menyampaikan risalah. Media dan agama tidak bisa dipisahkan dalam kehidupan bermasyarakat. Keduanya saling memberikan kontribusi yang nyata untuk melakukan perubahan. Nilai-nilai agama yang disampaikan melalui media massa mampu menjadi pembentuk kepribadian masyarakat (Syobah N, 2013). Tentu saja dalam hal ini pendakwah harus paham dan menguasai teknologi (Jannah, 2013).

Dakwah melalui media massa mampu meminimalisasi pemaksaan dalam beragama. Masyarakat bisa dengan bebas dan mudah mengakses informasi agama sesuai dengan yang dibutuhkan dan yang diinginkan. Saat ini media massa yang paling banyak digunakan oleh manusia adalah internet yang di dalamnya terdapat fasilitas seperti website, blog, Youtube dan fasilitas lainnya (Sadly, 2018).

Dakwah merupakan sebuah ajakan untuk mengubah diri pada ranah kebaikan. Dakwah di media massa memberikan pengaruh yang nyata di era saat ini. Para generasi milenium bisa dengan mudah mengakses informasi persoalan keagamaan dari media massa (Gofur, 2019). Masyarakat modern saat ini lebih mengandalkan informasi dari media massa (Mamdud, 2019).

Keterampilan dalam berdakwah perlu dilakukan agar bisa menghasilkan daya tarik dan bisa menjadi salah satu alternatif upaya untuk menginternalisasi nilai-nilai kepada masyarakat. Hal ini dikarenakan konstruksi media massa mampu mengubah pola pikir maupun tindakan masyarakat (Syobah N, 2013).

Peserta pengabdian di sini diharapkan mampu adaptif terhadap perkembangan IPTEK. Sebagai tindak lanjut dari pengabdian ini, peserta mampu meningkatkan pengetahuan tentang peran perempuan di era digital. Peserta mampu menjadikan dakwah sebagai kewajiban untuk 
mengubah kondisi sosial masyarakat. Peserta mampu memberikan kontribusi pemikirannya untuk menuliskan karyanya di media massa.

\section{Kesimpulan}

Pemberdayaan perempuan penting untuk dilaksanakan secara berkelanjutan karena hal ini berdampak pada peningkatan kualitas Sumber Daya Manusia (SDM). Perempuan berdaya menjadikan kekuatan dalam melakukan perubahan sosial. Hal tersebut membuktikan bahwa perempuan merupakan subyek perubahan. Melalui pelatihan kepenulisan, perempuan mampu menyampaikan gagasannya untuk melakukan pembenahan terhadap kondisi sosial masyarakat. Terlebih di era digital dan peran perempuan sebaiknya turut andil di dalamnya. Maka melalui pengabdian masyarakat ini adalah upaya untuk menyebarkan kesadaran bagi perempuan untuk mampu memberikan kontribusinya melalui gerakan literasi yang mampu menghasilkan tulisan yang bermakna untuk mencapai kesetaraan gender melalui digital. Penulis berharap akan ada kesinambungan gerakan literasi digital bagi para akademisi ataupun aktivis dalam rangka meningkatkan kesadaran ilmu pengetahuan kepada masyarakat yang mengangkat isu-isu krusial tentang perempuan.

\section{Ucapan Terima Kasih}

Terima kasih kepada Direktorat Penelitian Pengabdian Masyarakat Universitas Islam Indonesia yang telah mendanai pengabdian masyarakat dan kepada Pimpinan Wilayah Nasyiatul Aisyiyah Daerah Istimewa Yogyakarta yang telah bersedia menjadi mitra pengabdian.

\section{Referensi}

Bappeda DIY. (2017). Indikator Kinerja Pemda Pemberdayaan Perempuan dan Masyarakat. Dataku.

Gofur, A. (2019). Dakwah Islam Di Era Milenial. Dakwatuna, 5(2). https://doi.org/10.22515/balagh.v4i1.1557

Hanapi, A. (2015). Peran Perempuan Dalam Islam. Gender Equality: Internasional Journal of Child and Gender Studies, 1(1). https://jurnal.arraniry.ac.id/index.php/equality/article/view/620/513

Jannah, N. (2013). Media Dakwah Pop. At Tabsyir, 1(2), 26. https://www.academia.edu/download/56502896/432-1803-1-PB.pdf

Komariah, N, Prijana, dan Winoto, Y. (2018). Women empowerment meeting through health information literature training training among PKK cadres. Dharmakarya: Jurnal Aplikasi Ipteks Dan Masyarakat, 7(1), 26-31.

Mamdud, R. (2019). Dakwah Islam di Media Massa. Al-i'lam: Jurnal Komunikasi Dan Penyiaran Islam, 3(1), 47-54. http://journal.ummat.ac.id/index.php/jail/article/view/1366

Muhammad, H. (2014). Islam dan Pendidikan Perempuan. Jurnal Pendidikan Islam, 3(2). 
http://ejournal.uin-suka.ac.id/tarbiyah/JPI/article/view/1167/1063

Mulyasih, R. (2017). Pentingnya Literasi Media Bagi Kaum Perempuan. LONTAR: Jurnal Ilmu Komunikasi, 4(3). https://doi.org/10.30656/lontar.v4i3.364

Purnamasari, D. M. (2021). Konferensi G20 Pemberdayaan Perempuan, Menteri PPPA Tegaskan RI Perkuat Komitmen Kesetaraan Gender. Kompas.Com.

Puspita, H. (2016). Usaha Pemberdayaan Perempuan Melalui Pengembangan Kabupaten Sidoarjo Aisyiah and Creative Economy: Womens Empowerment Enterprises Through Familly Enterprises Development in Tanggulangin Districts of Sidoarjo. Prosiding Seminar Nasional Ekonomi Dan Bisnis, 383-393.

Sadly, E. (2018). Manajemen Dakwah Media Sosial: Telaah Terhadap Perkembangan Metode Dakwah Islam. Jurnal Riset Manajeman Dan Bisnis (JRMB), 3(2), 44. https://jurnal.uisu.ac.id/index.php/JRMB/article/view/902

Sasi. (2010). Dampak tindak kekerasan terhadap perempuan dan anak serta solusinya. Fhukum.Unpatti.Ac.Id, 16(3). https://fhukum.unpatti.ac.id/download/jurnalpaper/sasi/Jurnal SASI vol 16 no 3 Juli - September 2010/DAMPAK TINDAK KEKERASAN.... J. D. Pasalbessy.pdf

Suharli, M. L. (2021). Tantangan Pemberdayaan Perempuan. Media Indonesia.

Syobah N. (2013). Konstruksi Media Massa Dalam Pengembangan Dakwah. Jurnal Dakwah Tabligh, $\quad 14(2), \quad 153 . \quad$ https://journal.iainsamarinda.ac.id/index.php/lentera_journal/article/view/190

Widyastuti, D. A. R., Nuswantoro, R., \& Sidhi, T. A. P. (2016). Literasi Digital pada Perempuan Pelaku Usaha Produktif di Daerah Istimewa Yogyakarta. Jurnal ASPIKOM, 3(1), 1. https://doi.org/10.24329/aspikom.v3i1.95

Winarni Wahyu, R. (2010). Representasi Kecantikan Perempuan Dalam Iklan. Deiksis, 2(2), 134-152.

Zakiyah. (2010). Pemberdayaan Perempuan Oleh Lajnah Wanita dan Putri Al-Irsyad Surabaya. Analisa, XVII(01), 37-56. 